\title{
KEWJIBAN PENGUSAHA BUS UNTUK MEMBERIKAN TIKET KEPADA PENUMPANG ANGKUTAN UMUM TRAYEK PONTIANAK - SAMBAS
}

\author{
Stefanus Ngebi \\ Fakultas Hukum Universitas Kapuas Sintang \\ Jalan Yc. Oevang Oeray 92 Sintang \\ Email : stefanus_ngebi007@yahoo.co.id
}

\begin{abstract}
In the transportation of people using

bublic transportation, such as bus has regular

route. Public transportation entrepreneurs

have to do some rules such as give good

services to the passengers, provide comfort

fasilities, give a sense of secure for passengers

and insure the passengers to PT. Asuransi Jasa

Raharja.
\end{abstract}

Within the transportation also make transport agreement. It will appear incumbency between passengers and carriers. Based on the agreement, the incumbency make the carriers have the duty of carry away commodity to the right destination and the passengers have the duty to pay carfare. Moreover, the carriers is public transportation entrepreneurs must carry the passengers to the right destination and give the ticket to the passengers as evidence. The passengers must pay the ticket has already decided by public transportation entrepreneur.

Considering the problem was complete, especially traffic and transport on highway. The government has issued act number 14 year 2019 about traffic and road transport. People have to execute the government regulation. The government regulation number 41 year 1993 and in transportation minister decree number KM 35 year 2003 regulate about implementation the transport use public transport.

In connection with the organization, that is transportation of people on the road by using bus on route Pontianak-Sambas. Evidently, the transport entrepreneurs disobeying the provisions of the obligation to give tickets to the passengers as regulated in the law. On the other hand, there is no support from government agencies to provide facilities and infrastructure for exmple ticket sales at Batu layang and lack of supervision and guidance to public transpotation entrepreneurs, so they do deviations from the rules that already exist.

Key words : act against the law, incumbency public road transport route.
Abstrak
Dalam pengangkutan orang dengan mengunakan bus angkutan umum dalam 
66 Perahu, Volume 7 Nomor 2, September 2019, Hlm 65-80

bentuk trayek tetap dan teratur, tentu ada aturan main yang harus dilakukan oleh pengusaha angkutan umum tersebut seperti setiap pengusaha angkutan umum harus melayani penumpang dan menyediakan fasilitas untuk kenyamanan dan memberikan rasa aman penumpang serta mengasuransikan penumpang kepada PT. Asuransi Jasa Raharja.

Dalam pengangkutan juga timbul yang namanya perjanjian pengangkutan dan perjanjian pengangkutan tersebut akan menimbulkan hak dan kewajiban antara penumpang dan pengangkut. Oleh karena ada hak dan kewajiban tersebut maka pengangkut berkewajiban mengangkut atau mengantar barang ketempat tujuan sesuai dengan perjanjian dan penguna Jasa Angkutan berkewajiban membayar uang jasa angkut atau ongkos angkut. Selain dari pada itu pengangkut dalam hal ini adalah Pengusaha

Bus angkutan Umum harus mengantar penumpang atau orang (pengangkutan orang) sesuai dengan tempat tujuannya dan wjib memberikan tiket kepada penumpang sebagai bukti telah terjadinya perjanjian sementara penumpang (orang) wajib membayar tiket atau jasa angkutan sesuai dengan yang telah ditentukan oleh pengusaha angkutan umum tersebut.

\section{Mengigat semakin kompleksnya}

permasalahan, khususnya lalu lintas dan angkutan jalan raya dimasa sekarang, maka dalam pembinaan oleh pemerintah dikeluarkan Undang-Undang Nomo 14 Tahun 1992 Tentang Lalu Lintas dan Angkutan Jalan. Untuk melaksanakan peraturan Perundang-undangan yang telah dibuat tersebut, maka perlu dibuat lagi peraturan pelaksana yang disebut dengan peraturan pemerintah. Untuk pengaturan yang bersifat teknis dan operasional, khususnya untuk penyelenggarraan Angkutan Orang Di Jalan dengan kendaraan Umum adalah diatur dengan peraturan pemerintah nomor 41 Tahun 1993 Tentang Angkutan Jalan; Keputusan Menteri Perhubungan Nomor : KM 35 Tahun 2003 Tentang Pelenggaraan Angkutan Orang Dijalan Dengan Kendaraan Umum.

Sehubungan dengan penyelenggaraan tersebut yakni pengangkutan orang dijalan dengan mengunakan mobil bus pada trayek angkutan umum trayek pontianak-sambas, ternyata dalam pelaksanaannya dilapangan para pengusaha angkutan umum trayek pontianak-sambas, masih belum mentaati ketentuan kewajiban untuk memberikan tiket kepada penumpang sebagaimana yang diperintahkan oleh undang undang. Selain dari pada itu juga dukungan dari instansi pemerintah terkait, misalnya dinas perhubuangn kota pontianak dan propinsi yang belum maksimal untuk menyediakan 
sarana dan prasaran misalnya menyediakan

loket penjualan tiket di terminal batu layang, kurangnya responsifnya pemrintah atau dinas

terkait terhadap pengawasan dan pembinaan kepada para pengusaha angkutan umum sehingga situasi dan kondisi dilapangan ada beberapa kejadian-kejadian yang dilakukan oleh pengusha angkutan umum trayek pontianak-sambas yang menyimpang dari aturran yang sudah semestinyan ditentukan dalam lalu lintas dan angkutan jalan. Oleh karena itu dalam hal ini pengusha angkutan umum trayek pontianak-sambas ternyata melakukan perbuatan melawan hukum.

Kata kunci: perbuatan melawan hukum, Hak dan Kewajiban Trayek Angkutan Umum Jalan Darat dan Penumpang

\section{Pendahuluan}

Kondisi sosial masyarakat indonesia sekarang ini khususnya di daerah kalimantan barat semakin hari semakin meningkat, terlebih lagi dengan kemajuan jaman yang harus menuntut masyarakat untuk terus bergiat dalam menghadapi segala tantangan yang ada. Dengan berbagai keperluan atau kebutuhan kehidupan tentu perlu sarana dan prasarana yang bisa mendukung untuk menunjang akan tercapainya kebutuhan yang diperlukan.
Persoalan-persoalan tersebut ditambah lagi dengan pertumbuhan penduduk yang begitu padat, tentu berpengaruh terhadap seluruh aspek kehidupan, terkhusus transportasi darat dalam hal ini adalah Trayek Angkutan Umum di jalan.

Banyak masyarakat yang telah memiliki kendaraan pribadi tetapi banyak pula yang belum memiliki kendaraan pribadi, meskipun banyak masyarakat yang sudah memiliki kendaraan pribadi, ternyata untuk urusan berpergian keluar kota contohnya pergi ke pontianak atau ke sambas banyak masyarakat lebih memilih angkutan kendaraan umum atau trayek ketimbang mengunakan kendaraan

pribadi. Berbagai alasan kenapa banyak masayarakat lebih memilih mengunakan jasa angkutan umum ketimbang membawa kendaraan pribadi, salah satu alasan adalah efektif dan efisien dari segi biaya dan waktu, tidak capek dari segi fisik jika dibandingkan kita membawa atau menyetir mobil sendiri tentu juga ringan, belum lagi diliat dari segi resiko dapat diminimalisir.

Dalam pengangkutan orang melalui angkutan jalan pangkalan atau terminal wajib ada, pengusaha angkutan umum wajib memberikan tiket kepada setiap penumpang yang akan mengunakan bus angkutan umum, lain dari pada itu loket penjualan tiket serta petugas yang akan menjual atau memberikan 
tiket kepada calon penumpang yang akan mengunakan bus angkutan umum juga harus ada. Dalam konteks ini peneliti mengadakan penelitian terhadap trayek angkutan umum jurusan pontianak-sambas dimana pangkalan atau terminal induknya ada di terminal batu layang. Setiap penumpang yang naik diterminal batu layang harus membeli dan mempunyai tiket sesuai dengan kendaraan dan nomor kursi pada bus tersebut. Kenapa harus mempunyai tiket? Tiket merupakan suatu bukti perjanjian pengangkutan dan sebagai tanda lunas pembayaran angkutan, sehingga tiket itu wajib diberikan oleh pengusaha angkutan umum khusus trayek angkutan umum pontianak-sambas sebagaimana yang dinyatakan dalam pasal 84 Keputusan Menteri Perhubungan Nomor: KM 35 Tahun 2003

Tentang Penyelenggaraan Angkutan Orang

Di Jalan Dengan kendaraan Umum.

Oleh sebab itu sebelum Bus itu berangkat, Sopir Bus atau Kernet harus memeriksa terlebih dahulu para penumpangnya apakah semua penumpang yang naik itu sudah ada tiketnya. Penumpang yang sah adalah penumpang yang dapat menunjukan tiketnya ketika diminta oleh sopir atau kernet, sedangkan penumpang yang tidak sah adalah penumpang yang tidak bisa menunjukan bukti tiket ketika sopir atau kernet meminta tiket yang bersangkutan.

Akibat dari penumpang yang tidak mempunyai tiket oleh sopir atau kernet angkutan umum, penumpang yang bersangkutan dapat dikeluarkan dari bus atau disuruh terlebih dahulu membeli tiket ketempat pembelian tiket yang telah disediakan sesuai dengan jurusan trayek angkutan umum itu. Selain dari itu akibat yang

fatal bagi penumpang yang tidak mempunyai tiket adalah jika terjadi sesuatu dan lain hal, misalnya terjadi kecelakaan dijalan raya oleh kendaraan umum yang dinaiknya itu, maka bagi penumpang yang tidak mempunyai tiket oleh pengusaha angkutan umum tidak dapat dipertanggungjawabkan pada PT.

\section{Asuransi JASA RAHARJA sebagaimana} yang tertuang dalam Undang-Undang Nomor 33 Tahun 1964 Tentang Dana Pertanggungan Wajib Kecelakaan Penumpang Junto PP 17 Tahun 1965 Tentang Ketentuan-Ketentuan Pelaksanaan Dana Pertanggungan Wajib Kecelakaan Penumpang.

Oleh karena Karcis atau Tiket itu sangat penting fungsinya, maka pengusaha angkutan umum itu harus memberikan atau mempersiapkan karcis atau tiket kepada seluruh penumpang disertai dengan "Kupon Pertanggungan". Setiap bulan perusahaan angkutan umum atau pemilik angkutan umum wajib membayar iuran paling lambat tanggal 27, perusahaan angkutan umum atau pemilik bus angkutan umum tersebut menyetor iuran 
tersebut kepada perusahaan asuransi kerugian

“ Jasa Raharja”. Kewajiban tersebut wajib

dilakukan oleh perusahaan angkutan umum atau pemilik jasa angkutan umum atau trayek dan tidak bisa ditawar tawar, jika itu tidak diindahkan oleh trayek angkutan umum maka akan dikenakan denda sesuai dengan pasal $21 \mathrm{PP} / 65$, atau dicabut ijin usahanya untuk selama-lamanya tiga bulan sesuai dengan pasal 22 PP 17/65. Itulah alasan mendasar kenapa tiket itu wajib diberikan oleh pihak pengusaha angkutan umum atau trayek angkutan umum dan bagi penumpang wajib membeli tiket bus angkutan umum jika ingin bepergian mengunakan jasa angkutan umum terkhusus jurusan pontianak-sambas atau sebaliknya.

\section{Metode Penelitian}

Dalam penelitian ini mengunakan metode empiris dengan pendekatan diskriptif analisis yaitu suatu penelitian yang dilakukan dengan cara mengambarkan keadaan yang sebenarnya sebagaimana yang terjadi pada saat penelitian dilakukan. Selain dari pada itu juga penelitian ini mengunakan bentuk penelitian Kepustakaan (Library Research) dimana dengan mempelajari dan menghimpun data-data dari berbagai literatur, buku-buku, tulisan serta pendapat para ahli-ali, UndangUndang Terkait, Peratura-Peraturan seta bahan bahan yang ada hubunganya dengan masalah yang diteliti.

Subjek penelitian ini adalah pemilik trayek angkutan umum atau pengusaha trayek angkutan umum jurusan pontianak-sambas, dinas perhubungan provinsi, sopir bus serta petugas penjual tiket di terminal batu layanng

pontianak dan penumpang Bus Trayek angkutan Umum Pontianak-sambas.

Pembahasan

Dalam penelitian ini peneliti menentukan daerah penelitian di Kotamadya Tingkat II pontianak tentang kewajiban

Pengusaha Bus untuk memberikan tiket

kepada penumpang Angkutan Umum Trayek Pontianak-Sambas, dihubungkan dengan perbuatan melawan hukum yang dilakukan oleh pengusaha/sopir Angkutan umum jurusan trayek pontianak-sambas. Adapun yang menjadi populasi dalam penelitian ini adalah Dinas Perhubungan Provinsi Kalimantan Barat, Pengusaha Bus Trayek PontianakSambas, Sopir bus Trayek Pontianak-Sambas dan beberapa penumpang Angkutan Umum jurusan Trayek Pontianak-sambas. Dalam populasi itu peneliti akan mengambil sampel dari Dinas Perhubungan Daerah Provinsi Kalimantan Barat sebanyak 1 (satu) orng, Pengusaha Bus Trayek Pontianak-Sambas sebanyak 5 (lima) orang, sopir Bus Trayek Jurusan Pontianak-Sambas sebanyak 7 
(Tujuh) orang serta penumpang Bus Trayek

Jurusan Pontianak-Sambas $10 \quad$ (sepuluh)

orang.

\section{Menurut M.A. Moegni Djojodirdjo}

bahwa yang dimaksud dengan perbuatan melawan hukum adalah "merupakan suatu perbuatan atau suatu kealpaan perbuatan, yang melanggar hak orang lain atau bertentangan dengan kewajiban hukum si pelaku (orang yang telah melakukan perbuatan) atau melanggar, baik kesusilaan atau bertentangan dengan keharusan, yang harus diindahkan dalam pergaulan masyarakat tentang orang lain atau barang" 29 selanjutnya menurut

Rachmat Setiawan "suatu perbuatan yang tidak hanya bertentangan dengan undangundang pidana, tetapi juga bertentangan dengan undang-undang lain dan bahkan bertentangan dengan hukum yang tidak berlaku" ${ }_{30}$. Dalam pasal 1365 KUHPerdata juga menjelaskan perbuatan melawan hukum adalah "Tiap-tiap perbuatan melawan hukum yang membawa kerugian kepada orang lain yang karena salahnya menerbitkan kerugian tersebut, menganti kerugian tersebut". ${ }_{31}$

Sebagai langkah awal dari analisa data dalam penelitian ini, peneliti akan memaparkan terlebih dahulu mengenai

\footnotetext{
29 M.A. Moegni Djojodirjo, Perbuatan Melawan Hukum, Pradnya Paramita, Jakarta, 1982, Hal 25

30 Rachmat Setiawan, Tinjauan Elemen Perbuatan Melawan Hukum, Alumni, Bandung, 1982, Hal 5

31 Kitab Undang-Undang Hukum Perdata
}

penumpang yang pernah mengunakan Bus

Angkutan Umum Tryaek Pontianak-Sambas dalam tabel dibawah ini.

TABEL I

PENUMPANG YANG PERNAH

MENGUNAKAN TRAYEK ANGKUTAN

UMUM PONTIANAK-SAMBAS

\begin{tabular}{|c|l|c|c|}
\hline NO & ALTERNATIF & FREKUENSI & $\%$ \\
\hline 1 & PERNAH & 50 & 100 \\
\hline 2 & TIDAK PERNAH & 0 & 100 \\
\hline N=50 & 50 & 100 \\
\hline
\end{tabular}

Sumber data lapangan yang diolah

Dari tabel I tersebut diatas dapat dijelaskan dan diketahui bahwa dari 50 (lima puluh) orang penumpang responden (100\%) menyatakan pernah mengunakan trayek angkutan umum jurusan pontianak-sambas hal tersebut terlihat jelas dalam tabel diatas. Salah satu penyebab banyaknya peminat atau penumpang yang lebih memilih mengunakan bus trayek jurusan pontianak-sambas karena penumpang langsung dijemput oleh sopir bus trayek pontianak-sambas, dalam hal ini penumpang tidak perlu pergi ke terminal batu layang, terlebih lagi tidak harus repot-repot membeli tiket dulu baru bisa naik mengunakan bus trayek pontianak-sambas sebagaimana yang diperintahkan oleh PP (peraturan pemerintah nomor 41 tahun 1993 tentang angkutan jalan dimana dalam pasal 51 
Stefanus Ngebi, Kewajiban Pengusaha Bus Untuk Memberikan Tiket Kepada Penumpang 71

menyatakan bahwa :32

1. Awak kendaraan umum angkutan penumpang harus mematuhi ketentuan mengenai :

a. Tata cara menaikan dan menurunkan penumpang

b. Tata cara berhenti

c. Pengguna karcis atau pengguna biaya angkutan

d. Kelengkapan teknis kendaraan umum angkutan penumpang

2. Keputusanlebihlanjut sebagaimana dimaksudkan dalam ayat (1) diatur dengan keputusan menteri (KepMen)

Selanjutnya untuk mengetahui apakah penumpang trayek angkutan umum jurusan pontianak-sambas sebelum mengunakan bus atau naik bus angkutan umum trayek jurusan pontianak-sambas tersebut membeli tiket, dapat diliat dalam tabel dibawah ini

TABEL ॥

PENUMPANG YANG MEMBEI TIKET

SEBELUM MENGGUNAKAN TRAYEK

ANGKUTAN UMUM JURUSSAN

PONTIANAK-SAMBAS

\begin{tabular}{|c|l|c|c|}
\hline NO & ALTERNATIF & FREKUENSI & $\%$ \\
\hline 1 & MEMBELI & 3 & 6 \\
\hline 2 & TIDAK MEMBELI & 44 & 88 \\
\hline
\end{tabular}

$32 \quad$ Peraturan Pemerintah No. 41 Tahun 1993 tentang angkutan jalan

\begin{tabular}{|c|c|c|c|}
\hline 3 & $\begin{array}{l}\text { KADANG- } \\
\text { KADANG }\end{array}$ & 3 & 6 \\
\hline $\mathrm{N}=50$ & 50 & 100 \\
\hline
\end{tabular}

Sumber Data Lapangan Yang Diolah

Dari tabel II tersebut diatas dapat diketahui bahwa dari 50 (lima puluh) orang responden diatas sebanyak 3 (tiga) orang penumpang responden (6\%) menyatakan membeli tiket, 44 orang penumpang reponden $(88 \%)$ yang menyatakan tidak membeli tiket sedangkan yang kadang-kadang beli tiket atau tidak sebanyak 3 orang penumpang responden (6\%) yang menyatakan demikian.

Gambaran dari tabel II diatas dapat diambil kesimpulan bahwa banyak penumpang yang tidak memegang/memiliki tiket ketika mereka menggunakan atau menaiki bus trayek angkutan umum jurusan pontianaksambas tersebut.

Selanjutnya untuk mengetauhi apakah pihak penumpang pernah diberikan tiket atau tidak oleh pengusahan trayek angkutan umum pontianak-sambas dapat dilihat dalam tabel berikut.

TABEL III

PENUMPANG YANG PERNAH MINTA

TIKET KEPADA PENGUSAHA TRAYEK

ANGKUTAN UMUM PONTIANAK-

SAMBAS SEBELUM BERANGKAT

\begin{tabular}{|l|l|l|l|}
\hline NO & ALTERNATIF & FREKUENSI & $\%$ \\
\hline
\end{tabular}




\begin{tabular}{|r|l|c|c|}
\hline 1 & $\begin{array}{l}\text { PERNAH } \\
\text { MEMINTA }\end{array}$ & 4 & 8 \\
\hline 2 & $\begin{array}{l}\text { TIDAK } \\
\text { PERNAH } \\
\text { MEMINTA }\end{array}$ & 46 & 92 \\
\hline $\mathrm{N}=50$ & 50 & 100 \\
\hline
\end{tabular}

Sumber Data Lapangan Yang Diolah Dari tabel tersebut diatas dapat diketahui bahwa dari 50 (lima puluh) orang responden diatas, sebanyak 4 (empat) orang penumpang responden $(8 \%)$ menyatakan pernah meminta tiket, 46 0rang penumpang responden (92\%) yang menyatakan tidak pernah meminta tiket, artinya dari gambaran tabel III diatas dapat disimpulkan bahwa sebagian besar penumpang yang tidak diberikan tiket oleh pengusaha/sopir trayek angkutan umum jurusan pontianak-sambas tidak ada inisiatif untuk meminta tiket kepada pengusaha dalam hal ini dengan sopir angkutan umum terebut. Begitu juga sebaliknya, dengan melihat tabel III tersebut diatas mengambarkan juga bahwa inisiatif dari sopir angkutan umum terkait tiket penumpang wajib memiliki tiket belum maksimal.

Selanjutnya untuk mengetahui apaah pihak penumpang tahu bahwa penumpang yang bersangkutan wajib diasuransikan oleh pengusaha angkutan umum trayek pontinaksambas dapat dilihat dalam tabel berikut.

\section{TABEL IV}

PENUMPANG YANG MENGETAHUI
BAHWA PIHAK PENGUSAHA

ANGKUTAN UMUM TRAYEK

PONTIANAK-SAMBAS WAJIB

MENGASURANSIKAN PENUMPANG

\begin{tabular}{|c|l|c|c|}
\hline NO & ALTERNATIF & FREKUENSI & $\%$ \\
\hline 1 & MENGETAHUI & 34 & 68 \\
\hline 2 & $\begin{array}{l}\text { TIDAK } \\
\text { MENGETAHUI }\end{array}$ & 16 & 32 \\
\hline \multicolumn{2}{|l|}{$\mathrm{N}=50$} & 50 & 100 \\
\hline
\end{tabular}

Sumber Data Lapangan Yng Diolah

Dari tabel diatas dapat diketahui bahwa dari 50 (lima puluh) orang responden diatas, sebanyak 34 (tiga puluh empat) orang penumpang responden (68\%) menyatakan mengetahui bahwa penumpang wajib diasuransikan oleh pengusaha angkutan umum trayek pontianak-sambas, sedangkan 16 (enam belas) orang penumpang responden (32\%) menyatakan tidak mengetahuinya.

\section{Dari uraian data di tabel IV tersebut} dapat disimpulkan bahwa masih ada penumpang yang tidak mengetahui bahwa penumpang wajib diasuransikan oleh pengusaha angkutan umum. Selain dari pada data data diatas peneliti juga melengkapi dengan data-data wawancara terhadap responden-responden yang sudah peneliti tentukan seperti: Dinas Perhubungan daerah Provinsi Kalimantan Barat sebanyak 1 (satu) orng, PengusahaBus Trayek Pontianak- 
Sambas sebanyak 5 (lima) orang, sopir Bus

Trayek Jurusan Pontianak-Sambas sebanyak 7 (Tujuh) orang serta penumpang Bus Trayek Jurusan Pontianak-Sambas $10 \quad$ (sepuluh) orang.

Dapun hasil wawancara tersebut dapat disimpulkan sebagai berikut:

A. Hasil wawancara dengan dinas perhubungan Provinsi Kalimantan

Barat

1. Bahwa ada peraturan yang mewajibkan perusahaan angkutan orang di jalan dalam bentuk trayek untuk memberikan tiket kepada penumpang sesuai dengan pasal 43 Undang-Undang No. 14 tahun 1992 Tentang Lalu Lintas dan Angkutan Jalan.

2. Bahwa pihak yang menyediakan prasarana pendukung dalam melaksanakan pengangkutan orang di jalan seperti loket pembelian tiket bagi penumpang adalah pihak pemerintah yaitu dinas Perhubungan Kota Pontianak sesuai dengan kewenangannya.

3. Bahwa faktor yang menyebabkan loket pembelian tiket di batu layang tidak tersedia, salah satu penyebabnya adalah dinas perhubungan kota pontianak tidak optimal memperhatikan dalam hal anggaran untuk menyediakan loket pembelian tiket.

4. Bahwa kegunaan tiket bagi penumpang adalah sebagai bukti penumpang sudah melakukan kewajiban membayar tiket dan dijamin asuransi kecelakaan oleh PT. Jasa Raharja.

5. Bahwa jika terjadi kecelakaan dijalan raya dengan mengunakan angkutan umum pihak asuransi dalam hal ini adalah PT. Jasa Raharja memberikan santunan dengan melakukan program "Jemput Bola" dimana terjadi kecelakaan dengan dasar laporan kepolisian dan rumah sakit/ puskemas yang menangani korban dan setiap penumpang yang mengunakan kendaran tersebut akan dimintai tiket sebagai penumpang yang sah.

6. Bahwa setiap penumpang wajib diberikan tiket oleh pengusahasopir angkutan umum trayek pontianak-sambas

7. Bahwa bagi pengusaha trayek angkutan umum dalam bentuk trayek yang tidak memberikan tiket kepada penumpang dikenakan 
80 sanksipencabutan izin operasi

B. Hasil wawancara dengan pimpinan pengusaha angkutan umum trayek pontianak-sambas

1. Perusahaan

KOMAPON angkutan umum trayek pontianaksambas berdiri tahun 1981 .

1) Bahwa perusahaan tersebut mempunyai 29 unit kendaraan angkutan umum

2) Bahwa perusahaan tersebut tidak memberikan tiket kepada penumpang

3) Bahwa perusahaan tersebut tidak menyediakan loket penjualan tiket.

4) Bahwa faktor penyebab pihak perusahaan tersebut tidak menyediakan loket penjualan tiket disebabkan yang menyediakannya adalah pihak pemerintah kota pontianak dalah hal ini dinas perhubunagn kota pontianak.

5) Bahwa faktor penyeban perusahaan tersebut tidak memberikan tiket kepada penumpang dikarenakan kurangnya pembinaan dan pengawasan dari pihak pemerintah dalam hal ini adalah dinas perhubungan kota ataupun provinsi.

6) Bahwa perusahaan tersebut tidak mengetahui sanksi yang diberikan kepada pengusaha angkutan umum dalam bentuk trayek jika tidak memberikan tiket kepada penumpang yang disebabkan oleh kesimpangsiuran karena kurangnya pembianaan dari didinas terkait terhadap lalu lintas angkutan jalan orang khususnya di batu layang.

7) Bahwa tanggapan pemerintah dalam hal ini pemerintah kota dinas perhubungan pontianak yang kurang maksimal dan bersifat acuh tak acuh dengan situasi dan kondisi yang terjadi dilapangan, seperti banyak bus angkutan umum tidak melaksanakan antrian diterminal batu layang, banyaknya calok liar penjual tiket kepada penumpang sehingga sering terjadei keributan di dalam terminal batu layang, bus angkutan umum parkir tidak pada tempatnya. 
2. Perusahaan CV. Lintas Kapuas

Angkutan Umum Trayek

Pontianak-Sambas

1) Bahwa perusahan tersebut berdiri tahun 1980

2) Bahwa perusahaan tersebut mempunyai 36 unit kendaraan angkutan umum

3) Bahwa perusahan tersebut tidak memberikan tiket kepada penumpang

4) Bahwa faktor utama perusahaan tersebut tidak memberikan tiket kepada penumpang dikarenakan pihak perusahaan tersebut tidak menyediakan loket penjualan tiket, sementara yang menyediakan loket penjualan tiket di terminal batu layang adalah pihak dinas perhubungan kota pontianak.

5) Selain dari point nomor 4 faktor utama perusahaan angkutan umum tidak memberikan tiket kepada penumpang adalah karena penumpang lebih memilih di jemput dari pada harus pergi keterminal batu layang yang letaknya jauh sehingga penumpang merasa malas untuk membeli tiket.
6) Bahwa perusahaan tersebut tidak mengetahui sanksi yang diberikan kepada pengusaha angkutan umum dalam bentuk trayek jika tidak memberikan tiket kepada penumpang yang disebabkan oleh kesimpangsiuran karena kurangnya pembianaan dari didinas terkait terhadap lalu lintas angkutan jalan orang khususnya di batu layang.

7) Tanggapan pemerintah dalam hal ini belum optimal terhadap situasi dan kondisi yang ada dilapangan.

3. Perusahaan CV. Herlang angkutan umum trayek pontianak-sambas

1) Bahwa perusahaan tersebut berdiri pada tahun 1980

2) Bahwa perusahaan itu mempunyai 3 (tiga) unit kendaraan umum

3) Bahwa perusahaan tersebut hanya sebagian atau belum optimal memberikan tiket kepada penumpang

4) Bahwa perusahaan tersebut tidak menyediakan loket penjualan tiket

5) Bahwa perusahaan tersebut 
tidak mengetahui sanksi apa

yang diberikan jika tidak

memberikan tiket kepada

penumpang

4. Perusahaan PT. Sinar Abadi angkutan umum trayek pontianaksambas

1) Bahwa perusahaan tersebut berdiri pada tahun 1980

2) Bahwa perusahaan tersebut mempunyai 3 ( tiga ) unit

kendaraan.

3) Bahwa perusahaan tersebut tidak memberikan tiket kepada penumpang

4) Bahwa perusahaan tersebut tidak menyediakan loket penjualan tiket

5) Bahwa perusahaan tersebut tidak mengetahui sanksi apa yang diberikan jika tidak memberikan tiket kepada penumpang

6) Bahwa tanggapan pihak pemerintah terkait belum optimal dengan kondisi yang ada.

5. Perusahaan PT. Yuda Pratama Angkutan umum trayek pontianaksambas
1) Bahwa perusahaan tersebut

berdiri pada tahun 1980

2) Bahwa perusahaan tersebut mempunyai 6 (enam) unit kendaraan angkutan umum

3) Bahwa perusahaan tersebut tidak memberikan tiket kepada penumpang

4) Bahwa perusahaan tersebut tidak menyediakan loket penjualan tiket

5) Bahwa perusahaan tersebut tidak mengetahui sanksi apa yang diberikan jika tidak memberikan tiket kepada penumpang

6) Bahwa tanggapan pihak pemerintah terkait belum optimal dengan kondisi yang ada.

C. Hasil wawancara dengan sopir angkutan umum trayek pontianaksambas

1) Bahwa dari 7 (tujuh) orang responden sopir bus trayek pontianak-sambas yaitu 2 (dua) responden sopir bus trayek pontianak-sambas $(28,6 \%)$ menyatakan tidak mengatahui bahwa penumpang wajib diberikan tiket, sementara 5 (lima) responden 
sopir bus trayek pontianak-

sambas $(71,4 \%)$ menyatakan

mengetahui bahwa penumpang

wajib diberikan tiket.

2) Bahwa dari 7 (tujuh)

responden sopir bus trayek

pontianak-sambas yaitu 5

(lima) orang responden sopir

bus trayek pontianak-sambas

$(71,4 \%)$ menyatakan tidak

pernah memberikan tiket

kepada penumpang dan 2

(dua) orang responden sopir

bus trayek pontianak-sambas

(28,6\%) menyatakan kadang-

kadang bahkan jarang sekali

memberikan tiket kepada

penumpang.

3) Bahwa daei hasil

wawancara diatas dengan para

sopir angkutan umum trayek

pontianak-sambas rata-rata

hampir tidak pernah

memberikan tiket kepada

penumpang.

D. Hasil wawancara dengan penumpang angkutan umum trayek pontianaksambas

1) Bahwa dari 10 (sepuluh) orang responden penumpang

bustrayekpontianak- sambas menyatakan pernah menggunakan jasa angkutan umum trayek pontianaksambas

2) Bahwa dari 10 (sepuluh) orang responden penumpang bus trayek pontianak-sambas yaitu 2 (dua) responden penumpang bus trayek pontianak-sambas (20\%) menyatakan tidak mengetahui bahwa penumpang wajib diberikan tiket, sementara 8 (delapan) responden sopir bus trayek pontianak-sambas $(80 \%)$ menyatakan mengetahui bahwa penumpang wajib diberikan tiket.

3) Bahwa dari 10 (sepuluh) penumpang hanya 1 (satu) orang penumpang (10\%) responden yang mengetahui bahwa penumpang wajib diasuransikan, sementara 9 orang (90\%) responden penumpang menyatakan tidak mengetahui bahwa penumpang wajib diasuransikan.

4) Bahwa dari hasil wawancara diatas dengan penumpang angkutan umum trayek pontianak-sambas rata-rata 
78 Perahu, Volume 7 Nomor 2, September 2019, Hlm 65-80

hampir tidak mengetahui

bahwa penumpang wajib

diasuransikan oleh perusahaan

trayek angkutan umum jurusan

pontianak-sambas.

\section{Simpulan}

1. Bahwa

pengusaha/Sopir

angkutan umum trayek pontianaksambas belum maksimal memberikan tiket kepada penumpang

2. Bahwa penumpang banyak yang tidak mengetahui jika penumpang wajib diasuransikan oleh pengusaha angkutan umum trayek pontianaksambas kepada PT. Asuransi Jasa raharja.

\section{Adapun faktor yang menyebabkan} pengusaha/sopir angkutan umum trayek pontianak-sambas tidak memberikan tiket kepada penumpang dikarenakan salah satunya kurangnta pembinaan dan pengawasan dari dinas perhubunga kota dan propinsi kalimantan barat.

4. Adapun akibat hukum bagi pengusaha angkutan umum trayek pontianaksambas yang tidak melaksanakan kewajiban memberikan tiket kepada penumpang dapat dicabut ijin operasi trayek angkutan umum tersebut.
5. Adapun upaya yang dilakukan oleh penumpang yang tidak mendapatkan tiket pada saat naik jasa angkutan umum tersebut dapat minta tiket kepada sopir/kernet angkutan umum tersebut atau bisa melaporkan kepada dinas perhubungan terkait.

Melihat kesimpulan diatas peneliti meyarankan beberapa hal antara lain :

1. Untuk kenyamanan dan keselamatan penumpang, pengusaha angkutan umum trayek pontianak-sambas wajib memberikan atau menyediakan pelayanan dan fasilitas demi kelancaran dalam melakukan pengangkutan orang dijalan.

2. Untuk keamanan dan ketertiban lalu lintas dijalan raya pengusaha bus angkutan umum trayek pontianaksambas wajib melakukan antrian diterminal batu layang sebgaimana yang telah ditentukan oleh pihak yang berwewenang dan tidak ada bus angkutan umum trayek pontianaksambas yang menaikan dan menurunkan penumpang diluar terminal batu layang.

3. Pemerintah baik pemerintah kota pontianak maupun pemerintah propinsi dalam hal ini adalah dinas perhubungan harus tanggap serta 
Stefanus Ngebi, Kewajiban Pengusaha Bus Untuk Memberikan Tiket Kepada Penumpang 79

peduli dengan situasi dan kondisi yang terjadi di terminal batu layangdemi kelancaran dan ketertiban serta keamanan dalam melakukan pengangkutan orang dijalan.

\section{Daftar Pustaka}

Muhammad, Abdulkadir, Hukum Perikatan, PT.Citra Aditya Bakti, Bandung, 2000

Hukum

Pengangkutan Niaga, PT. Aditya Bakti, Bandung, 1998

,Hukum Perdata

Indonesia, PT. Aditya Bakti, Bandung, 1990

hukum

pengangkutan darat, laut, udara, PT. Aditya

Bakti, Bandung, 1994

Djojodirjo, Moegnio, Perbuatan Melawan

Hukum, Pradnya Paramita, Jakarta, 1982

Harahap, M.Yahya, Segi-Segi Hukum

Perjanjian, Alumni, Bandung, 1986

J. Sastrio, Hukum Perjanjian (Perjanjian Pada Umumnya), PT. Aditya Bakti, Bandung, 1992 Purwosutjipto, Pengertian Pokok Hukum

Dagang Indonesia, Bentuk-Bentuk Perusahaan

2, Djambatan, Jakarta

Pengertian pokok hukum

dagang indonesia, 3 hukum pengangkutan,

Djambatan, Jakarta, 2003

------------ , Pokok-Pokok Hukum

Dagang Indonesia (Hukum Pertanggungan),
Djambatan Jakarta

R. Subekti, Aneka Perjanjian, Alumni, Bandung. 1985

Tjitrodudibio, Kitab Undang-

Undang Hukum Perdata, Pradnya Paramita, Jakarta,

, Hukum Perjanjian Cetakan XV,

PT. Intermasa, Jakarta, 1994

UU No. 2 Tahun 1992 Tentang Usaha

Perasuransian

UU No. 14 Tahun 1992 Tentang Lalu Lintas dan Angkutan Jalan

UU No. 33 junco PP. 17 Tahun 1965 Tentang

Santunan Jasa Raharja

PP No. 41 Tahun 1993 Tentang Angkutan

Jalan

Keputusan Menteri Perhubungan Nomo KM

35 Tahun 2003 Tentang Penyelenggaraan

Angkutan Orang Di Jalan Dengan Kendaraan

Umum

Keputusan Direktorat Jendral Perhubungan

Darat Nomor: SK.1186/HK.402/DRJD/2002

Tentang Pemberian Sanksi Administrasi

Terhadap Pelanggaran Yang Dilakukan Oleh

Pengusaha Angkutan Penumpang Umum

Dalam Trayek Tetap dan Teratur 
